\title{
PRESIDENTIAL ADDRESS \\ THE IMPORTANCE OF AGRICULTURAL RESEARCH TO NEW ZEALAND'S FUTURE
}

\author{
AgResearch Grasslands, Private Bag 11008, Palmerston North \\ derek.woodfield@agresearch.co.nz
}

\begin{abstract}
Agricultural research has provided, and will continue to provide, substantial returns on investment for New Zealand. The need for ongoing investment in plant research in New Zealand is highlighted by the fact that $43 \%$ of our total export earnings are generated from five major plant species. Estimates of the returns from investment in $R \& D$ are about $\$ 8$ for each $\$ 1$ invested, which even with discounting for the lag between investment and return, has shown a benefit to cost ratio of approximately $3: 1$. The current level of public and private investment in $R \& D$ is well below average among OECD nations, and New Zealand's $R \& D$ environment is unstable, with large shifts in funding leading to loss of key research capabilities. Integrated research teams that have strong industry involvement offer the best conduit for communication between the developers and adopters of new technologies. Identification and support of these teams will improve adoption rates and provide long-term competitive advantages for New Zealand agriculture.
\end{abstract}

Keywords: agricultural research, economic growth, research funding, technology adoption

\section{Introduction}

New Zealand depends more heavily on its biological resources than any other developed nation. In fact our economic well-being is heavily dependent upon five plant species; radiata pine
(P inus radiata), kiwifruit (Actinidia chinensis), apple (Malus pumila), ryegrass (Lolium perenne) and white clover (Trifolium repens).

Pinus radiata accounts for approximately $90 \%$ of New Zealand's forestry export earnings of $\$ 3.5$ billion (MAF 2002), and two horticultural species, kiwifruit $(30 \%)$ and apples $(17 \%)$ account for nearly $50 \%$ of New Zealand's $\$ 2$ billion horticultural export earnings (Table 1; Kerr et al. 2001). Similarly, perennial ryegrass and white clover dominate the permanent pastures from which New Zealand earned approximately $\$ 13$ billion in exports last year (MAF 2002). The accumulated contribution of these five species generates approximately $69 \%$ of our primary industry exports, and $43 \%$ of New Zealand's total export income (Table 1).

The success of these species is clearly due to New Zealand's favorable temperate climate, however, there is no doubt that their economic importance has been enhanced through substantial public and private investment in research and development (R\&D). R\&D has underpinned the development of systems and infrastructures over several decades that maximize the strengths and minimize the weaknesses of these species.

A recent report by the $N Z$ Institute of Economic Research analysed areas of our economy that had a competitive advantage internationally, and changes in competitive advantage that had occurred between 1985 and 1999 (Ballingall \&

Table 1 Contribution of five plant species to New Zealand export earnings in 2001.

\begin{tabular}{lcccc}
\hline Industry & $\begin{array}{c}\text { Export returns } \\
\text { 2001 }\end{array}$ & Plant species & \multicolumn{2}{c}{ Export earnings for each species } \\
\hline & $(\$ M)$ & & $(\%$ of sector & $(\$ M)$ \\
Forestry & 3,569 & Radiata pine & export returns $)$ & $30^{2}$ \\
Horticulture & 1,952 & Kiwifruit & $30^{3}$ & 585 \\
\multirow{2}{*}{ Pastoral } & 13,893 & Apples & $17^{3}$ & 339 \\
& & Perennial ryegrass/ & 65 & 9,030 \\
& white clover & &
\end{tabular}

1 Source: www.maf.govt.nz/statistics/internationaltrade.

2 Source: www.maf.govt/statistics/primaryindustries.

${ }^{3}$ Source: Kerr et al. (2001). 
Briggs 2002). Among the ten most internationally competitive products that New Zealand exports, eight were meat (e.g. mutton), wool (e.g. greased and degreased), dairy (e.g. butter and dry milk/ cream) or generic animal products (horns and bones), while the remaining two were wood pulp and fresh apples. Similarly, many of the products that had shown good gains in competitive advantage since 1985 were also primary industry products. Ballingall \& Briggs (2000) concluded that: "There are no 'silver bullets'. New Zealand's comparative advantage remains largely with agricultural, horticultural and forestry-based products". Furthermore, while New Zealand must continue to push for further trade liberalisation for primary products, their study also suggested that to improve New Zealand's economic growth more emphasis needed to be placed on improving the efficiency, and encouraging innovation, in the industries with an existing

Figure 1 competitive advantage.

\section{Contribution of agric ultural research to economic development}

The contribution of research to the productivity and economic performance of the agricultural sector is difficult to assess frequently. The main outcome from research is knowledge and it is both the quality of this knowledge and the degree to which this knowledge can be applied to existing and new production systems that generates a return on investment (added value). A long lag-time frequently exists between the time investment is made and the time when the return from any knowledge and added value products is realized in biological systems. Conversely, returns on research investment are also frequently long-lived. Dick et al. (1967) reported that the impact of new knowledge generated from agricultural research reaches a peak after about 11 years and results in benefits for 23 years on average.

Several studies have demonstrated the significant returns from investment made in agricultural research. A study by Scobie \& Eveleens (1986) quantified the contribution of research to New Zealand agricultural productivity over almost sixty years (1926-1984). They reported a return of $\$ 8.55$ for each $\$ 1$ invested in agricultural $R \& D$, and even after discounting due to the time period over which the benefits occur (average 23 years), the ratio of benefits to costs was still 2.8 to 1 . This is a substantial return for any investment. Mclvor \& Aspin (2001) demonstrated that Meat NZ investment into $R \& D$ also returned $\$ 8$ to the meat industry for each dollar invested. The impact of research outcomes on the transformation of the sheep industry was highlighted by both Fraser (2000) and Caradus (2002).

I am not aware of any comparable study for the dairy industry, however, Caradus \& Clark (2001) highlighted outcomes from forage production and animal nutrition research that have improved the international competitiveness of the dairy industry. This competitive advantage is reflected by increases in days-in-milk (Caradus $\&$ Clark, 2001), milksolids (MS) production per cow (Woodfield 2001), and in lower production costs

The cost of liquid milk production (including labour and production costs) in New Zealand compared to ten international competitors. (Source: NZDB, IFCN Milk report, OECD).

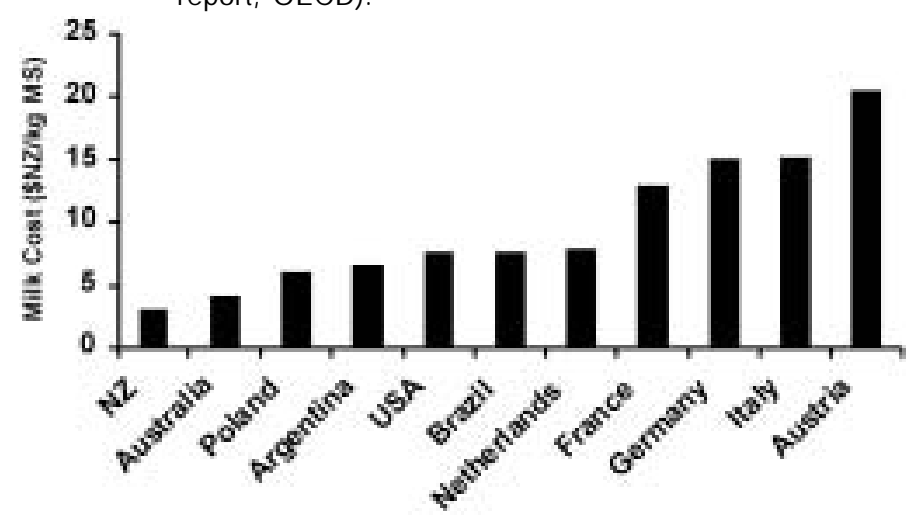

per $\mathrm{kg}$ MS than our international competitors (Figure 1). Furthermore, 25\% of milk revenues currently come from products developed in the past five years, but based upon 20 years of research and development. Product differentiation within the dairy industry has resulted in the development of 2100 different milk products.

$R \& D$ investment in the horticultural industry has resulted in New Zealand having the highest kiwifruit yields (approx. 21 tonnes/ha) in the world, and the second highest apple yields (around 40 tonnes/ha) in the world (Kerr et al. 2001). Similarly, investment in $R \& D$ and essential infrastructure has seen the wine industry grow from a $\$ 3 \mathrm{M}$ export industry in 1985 to $\$ 198 \mathrm{M}$ in 2001 (Kerr et al. 2001). The recent deregulation of the producer boards has resulted in a dramatic reduction in industry funding of horticultural research. This in 
turn has affected Government funding of horticultural research (see below).

\section{Investment levels in agric ultural $R \& D$}

Last year I stated that a stable research and development funding environment would encourage the innovation needed for agriculture to remain a major economic contributor to New Zealand (Woodfield 2001). Over the past year there have been positive and negative changes in New Zealand's R\&D funding environment. The first of these changes has been the completion of the first round of FRST "advancement". This advancement saw considerable reallocation of funds within and between science organisations. Crown Research Institutes (CRIS) gained \$7M in some portfolios and lost $\$ 13 \mathrm{M}$ in others (Hay 2002). The largest impact was on HortR esearch, which lost more than $\$ 5 \mathrm{M}$ or $33 \%$ of the funding it had up for advancement. However, even in organizations that retained most of their funding or had small increases, there were large shifts in capability. For example, Forest R esearch received a $\$ 1 \mathrm{M}$ increase for biotechnology research, while losing $\$ 1.1 \mathrm{M}$ for wood quality research (Hay 2002). Clearly many of the scientists who lost their funding cannot become biotechnologists overnight! This was by no means an isolated occurrence, and is likely to be repeated in this year's funding round.

The FRST advancement process has shifted funding away from research aimed at providing incremental production and efficiency gains for the primary industries. The underlying ideology is that investing in $R \& D$ with the potential to create a totally new product or indeed a new biologically- based industry will generate more wealth and provide greater competitive advantage for New Zealand. As a result a clear shortfall is appearing in the funding of the productivity and efficiency research that has driven the success of New Zealand agriculture to date. FRST's ideological shift is predicated upon industry providing funding for these often generic research areas. A positive initiative following industry deregulation has seen dairy farmers vote in favour of a levy for $R \& D$ and the formation of Dairy Insight to administer these levies. Similar levy initiatives for the meat and wool industries are being developed by Meat and Wool Innovation Limited.

These industry moves go some way towards the G overnment's goal of increasing industry $R \& D$ investment. However, they are also a doubleedged sword. Firstly, farmer levies can be extremely volatile because they are open to manipulation through industry politics, and to the economic climate each time the levy comes up for reconfirmation. Secondly, there may not actually be any investment increase, since the previous industry boards already had substantial $R \& D$ portfolios which must now be funded from these levies.

New Zealand's overall R\&D expenditure remains an issue. Internationally we ranked $20^{\text {th }}$ in 1999 for investment in $R \& D$ as a percentage of our total GDP (F igure 2). F urthermore, our position deteriorated between 1998 and 2000, with total $R \& D$ expenditure decreasing from 1.13 to $1.05 \%$ of GDP (MRST 2002). Government funding to Universities (funded on the basis of number of fulltime students) fell from $\$ 144 \mathrm{M}$ to $\$ 105 \mathrm{M}$, while overseas business $R \& D$ investment halved

Figure 2 Research and development spending in 1999 as a percentage of total GDP for each country (Reproduced from Economist 361 (8245), Oct 27, 2001 p104).

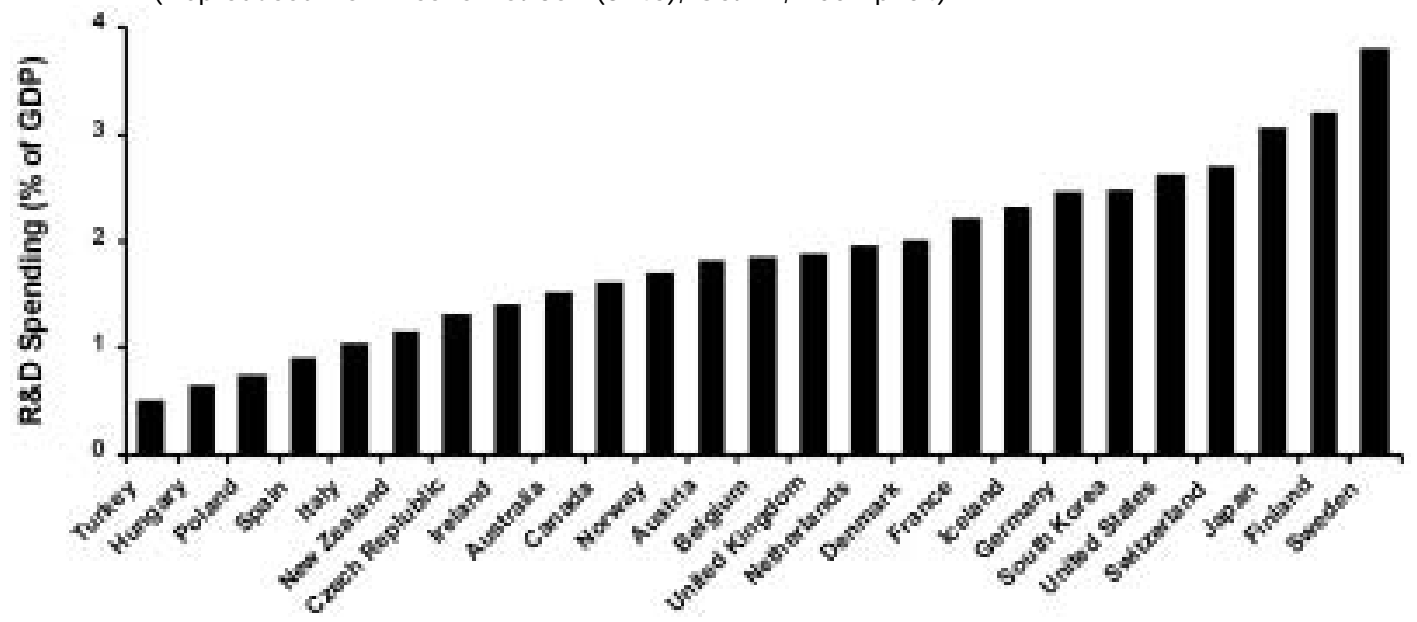


between 1998 and 2000. This drop in overseas investment into New Zealand has been most noticeable in the pharmaceutical industry, for which other countries offer considerable taxation breaks and other financial incentives to attract and retain these industries.

The impact of reductions in funding will not be immediately evident because there is a significant lag before the foregone productivity and output become apparent. Scobie \& Eveleens (1986) estimated that reductions in $R \& D$ would result in lower future productivity growth in agriculture, with funding reductions of $7.5 \%$ per annum resulting in a loss of $\$ 2.90$ per dollar reduction.

The other positive initiative this year is the formation of Research Consortia. This has provided direct leverage of government funding from industry investment. To date, these Consortia have been formed around specific topics (e.g. methane, meat quality and gene discovery in clover) that have relevance to the pastoral industries. It remains to be seen whether or not these new administrative structures will provide better returns on $R \& D$ investment and better adoption of innovations.

The only way to drive innovation without losing productive science teams and key capabilities is for genuinely new investment to be put in by the Government and private sectors. My personal belief is that without significant new $R \& D$ investment NZ science will continue to be eroded by the high level of instability and our insanely bureaucratic $R \& D$ funding process. This will ultimately affect our ability to deliver the innovations that Ballingall \& Briggs (2002) stated are required to keep our pastoral industries at the international forefront.

\section{Collaboration and Integrated research teams}

Over recent years an increasing number of reports have highlighted poor collaboration in New Zealand science. The reportedly poor levels of collaboration can be linked partly to the strong profit directive enforced on CRIs by CCMAU, the treasury unit overseeing the CRIs, and partly to the competitive culture resulting from contestable $R \& R$ funding. It can also be linked to the drive to protect intellectual property (IP) that has reached epidemic proportions in all New Zealand organisations, whether they are Government-, industry- or private-owned.

Protection of IP is in reality a global phenomenon, with thousands of patent applications piled up in patent offices worldwide.
The full impact of this drive to protect IP will not be evident for many years, however, it is clear that many opportunities to add value to our pastoral sector will be constrained by patented technologies. This will require complex negotiations to license the various IP required to develop future technologies and products. For example, negotiating a path through the myriad of molecular biology patents that are of potential benefit to New Zealand is nothing short of a minefield.

Given that the IP minefield is unlikely to go away in the foreseeable future, I do not see the level of collaboration between organisations being solved simply by funding criteria that favour multiple-organisation programmes. While the sentiment is genuine, collaboration has not, and never will be, an end in itself. In reality, collaboration must bring together the critical mass of people with the best range of skills needed to achieve a useful outcome. Mclvor \& Aspin (2001) identified five factors common to successful outcomes of research, technology transfer and uptake (i.e. changed behaviours):

1. Peer support and commitment

2. Participatory learning

3. Partnership between science, consultants, agribusiness and farmers

4. All projects involved experts in learning and communication

5. Practically harnessing the drive of farmers in developing and owning the project throughout its life

The integrated solutions approach described by Mclvor \& Aspin (2001) works because every participant has a role and brings an important set of skills to the project. It also values the contributions of all participants.

The development of the non-toxic ryegrass endophyte strain AR 1 is an excellent example of what can be achieved with an integrated team approach (Easton et al. 2001). This multidisciplinary team involved mycologists, entomologists, biochemists, agronomists, ecologists, plant breeders, reproductive biologists and animal scientists. Furthermore, industry groups such as Meat NZ and various seed companies have invested heavily in the research required prior to commercial release of $A R 1$ (Easton et al. 2001).

Molecular biology is currently a key Government platform for economic growth, attracting a high proportion of funding in the biological sciences. However, integrated teams will be required in order for the outcomes of this research to have 
the maximum impact on our pastoral industries. Integrated teams take years to set up because different sets of skills are required at different stages of the project. It is this very aspect that makes integrated research teams so susceptible to the vagaries of science funding. Teams that have taken years to build up can be decimated by funding cuts overnight.

\section{Technology adoption}

Early adoption of new technologies provides a competitive edge. New Zealand farmers are innovative and they are generally strong adopters of new technologies with some good examples being the introduction of aerial topdressing, rotational grazing, subdivision, electric fencing, feed budgeting, uptake of proprietary cultivars, and pregnancy scanning. However, to ensure that we remain internationally competitive, New Zealand farmers will need to be even better adopters of new technologies in the future.

A recent report on adoption of genetically modified (GM) crops in the USA, highlighted the speed with which various GM crops have been adopted (Fernandez-Cornejo \& McB ride 2002). The adoption of herbicide-tolerant crops has been particularly rapid with herbicide-tolerant soybeans going from first introduction in 1996 to $68 \%$ of total acreage in 2001 , while herbicidetolerant cotton increased from $10 \%$ of the cotton production area in 1997 to $56 \%$ in 2001 .

Fernandez-Cornejo \& MCBride (2002) also identified factors that affected adoption rates of GM technologies in the USA. These included pest/ weed infestation levels, seed price, cost of alternative treatments, farm size (larger farms had a higher proportion of early adopters) and education level (more educated or experienced farmers also early adopters). However, the most common reason farmers gave for adoption was simpler management and reduced labour costs.

Integrated research teams that have strong industry involvement offer the best conduit for communication between the developers and adopters of new technologies. I believe that investment in these teams will have the greatest long-term benefits for New Zealand.

\section{REFERENCES}

Ballingall, J .; Briggs, P. 2002. A look at New Zealand's comparative advantage: Updating the Porter Study's analysis of exports. N.Z Institute of Economic Research Working Paper 2002/04. $86 \mathrm{pp}$.
Caradus, J.R. 2002. Generating wealth from our primary resources. Proceeding of NZIAS/ NZSHS Forum on "Preserving New Zealand's wealth generating capacity": 10-11.

Caradus, J .R.; Clark, D.A. 2001. Advancing dairy farming profitability through research. Proceedings of the New Zealand Grassland Association 63: 17-22.

Clark, D.A.; Matthew, C.; Crush, J .R. 2001. More feed for New Zealand dairy systems. Proceedings of the New Zealand Grassland Association 63: 283-288.

Dick, I.D.; Toynbee, P.A.; Vignaux, G.A. 1967. Research as an investment. New Zealand J ournal of Science 10: 599-635.

Easton, H.S.; Christensen, M.J .; Eerens, J .P.J .; Fletcher, L.R.; Hume, D.E.; Keogh, R.G.; Lane, G.A.; Latch, G.C.M.; Pennell, C.G.L.; Popay, A.J .; Rolston, M.P.; Sutherland, B.L.; Tapper, B.A. 2001. Ryegrass endophyte: a New Zealand success story. Proceedings of the New Zealand Grassland Association 63: 37-46.

Fernandez-Cornejo, J.; McBride, W.D. 2002. Adoption of bioengineered crops. U.S. Department of Agiculture, Agricultural Economic Report No. 810.62 pp.

Fraser, T. 2000. Presidential address. Proceedings of the New Zealand Grassland Association 62: 1-2.

Hay, R.J.M. 2002. Career challenge for employers in science: the current situation in CRIs. Presentation to NZ Institute of Agricultural Science forum "P reserving New Zealand's wealth generating capacity". Massey University, J une 27, 2002.

Kerr, J .P.; Hewett, E.W.; Aitken, A.G. 2001. New Zealand horticultural facts and figures. $25 \mathrm{pp}$. HortResearch (www.hortresearch.co.nz).

Ministry of Research, Science and Technology. 2002. Biennial Report detailing New Zealand's $R \& D$ statistics. (www.morst.govt.nz).

Mclvor, S.D.; Aspin, M.D. 2001. R\&D success stories and principles to practice. Proceedings of the New Zealand Grassland Association 63: 23-27.

Scobie, G.M.; Eveleens, W.M. 1986. Agricultural research: whats it worth. Proceedings of the Ruakura Farmers' Conference 38: 87-92.

Woodfield, D.R. 2001. Agriculture: a key contributor to New Zealand's knowledge economy. Proceedings of the New Zealand Grassland Association 63: 1-6. 